[Higgins, N., MacArthur, J., \& Morton, M. (2008). Winding Back the Clock: The Retreat of New Zealand Inclusive Education Policy. New Zealand Annual Review of Education, 17, 145-167]

\section{Winding Back the Clock: The Retreat of New Zealand Inclusive Education Policy}

\author{
NANCY HIGgINS, JUDE MACARTHUR AND MISSY MORTON
}

\section{Abstract:}

In 1996 the New Zealand Ministry of Education stated its aim to develop a "world class inclusive education system". Through an analysis of current legislation and policy documents, this article argues that this policy has shifted, and the "clock is being wound back". More children are enrolling in Special Schools, in keeping with neoliberal ideologies focused on consumer choice, outcomes, and the view that education is a private good and not a human right. There are unclear and at times contradictory messages about "special" and "inclusive" education that result in an education system that has no clear path forward towards inclusion. The focus is instead on "special" education policy, the maintenance of placement choice, and the surveillance and management of disabled students. It is suggested that the way forward is for radical systemic change, the development of a clear inclusive education policy, and an ideological focus on social justice.

The recently released Ministry of Education's Statement of Intent 2007-2012 states its commitment to the New Zealand Disability Strategy. The Statement has particular significance for students with special education needs in Aotearoa New Zealand. One of the Ministry's three focused paths within this Statement over the next five years is to lead and support change so "that the education system values, respects, and is successful for all children and young people, in particular Maori, Pasifika, and students with special education needs (Ministry of Education, 2007 e, p. 30, italics added). This focus emerged from a concern over performance issues (p. 31) across the education system in which the gap between the highest and lowest achievers "remain(ed) wide by international standards" (p. 31).

\section{Nancy Higgins, Jude MacArthur and Missy Morton}

Since New Zealand's commitment to develop an inclusive education system in 1996 (Ministry of Education, 1996), a number of New Zealand researchers have also written about, and critiqued, such performance issues. This work provides a growing body of evidence that New Zealand's neoliberal paradigms (with their emphasis on the individual and on education as a private commodity), and mixed messages about education for disabled children, have limited the country's progression towards an inclusive education approach, where the focus is on a quality education for all children (Ballard, 2004; Bevan-Brown, 2006; Brown \& Thomson, 2005; Caroll-Lind, Bevan- Brown \& Kearney, 2007; Education Review Office (ERO), 2005; Gordon \& Morton, in press; Higgins, MacArthur \& Kelly, in press; Higgins, MacArthur, \& Reitveld, 2006; Kearney \& Kane, 2006; MacArthur, Sharp, Gaffney \& Kelly, 2007; MacArthur, Sharp, Kelly \& Gaffney, 2007; Millar \& Morton, 2007; Morton \& Gordon, 2006; Wills, 2006).

These researchers has consistently pointed to the lack of progress towards the Ministry of Education's 1996 Special Education 2000 policy (SE2000) goal to "achieve, over the next decade, a world class inclusive education system that provides learning opportunities of equal quality to all students" (Ministry of Education, 1996, p. 1). This paper explores this policy retreat and considers its impact on disabled children's educational experiences in Aotearoa New Zealand.

\section{Understanding Inclusion}

The terms "inclusion" or "inclusive education" are frequently misrepresented and misunderstood both in public forums and in the research literature. A common misconception is that inclusion is synonymous with "mainstream" education (Munoz, 2007). However, researchers who have developed thinking in this area have emphasised that inclusion involves deliberate and systemic change in education, so that schools can respond in positive ways to student diversity. British researcher, Mel Ainscow, encapsulates this idea when he describes inclusive education as

a process of increasing the participation of pupils in, and reducing their exclusion from, the cultures, curricula, and communities of their local schools, not forgetting, of course, that education involves many processes that occur outside of school. (Ainscow, 1999, p. 218)

Inclusion applies to efforts to meet the diverse needs of all students within an equitable and accepting education system founded in social 
justice (Ballard, 2004; Slee, 2001). Inclusive schools work to ensure that all students take a full and active part in school life and are valued and integral members of the school community and regular classroom (Nakken \& Pijl, 2002). School systems that work toward inclusion focus on change at the level of educational policy; school organisation, structure and ecology; and pedagogy (Booth, 2002; Education Queensland, 2001)

We are writing this paper as the new curriculum is being implemented in New Zealand schools (Ministry of Education, 2007a). Key foundation principles for curriculum decision-making reflect the current international focus on inclusion and provide sound support for a responsive shift in New Zealand education policy. The fourth principle, "Inclusion", describes the curriculum as

non-sexist, non-racist, and non discriminatory; it ensures that students' identities, languages, abilities, and talents are recognised and affirmed and that their learning needs are addressed. (p. 9)

The principle of "High expectations" refers to the support given by the curriculum for all students to learn, regardless of their individual circumstances. The "Community engagement" principle emphasizes the importance of the curriculum in its connections with students' families, whanau, and communities. The other principles similarly emphasize that the curriculum is for all students. In addition, the values to be encouraged and explored within the curriculum include equity through fairness and social justice. Consistent with ideas about social justice, the curriculum encourages students "to respect themselves, others, and human rights" (p. 10). However, it does not explicitly relate inclusion or diversity to disability, disabled children or to learning in regular classroom settings.

\section{A Shifting Focus in "Special" Education}

The special education policy framework known as Special Education 2000 was first announced in the 1996 Budget to guide resourcing for children and young people with special education needs. (Ministry of Education, 2007c). Its forward-thinking aim for an inclusive education system guided the compulsory school sector until 2005 (Education Review Office, 2005), but can nolonger be found on the Ministry's website page, entitled Special Education Policy. Instead, this web page provides a brief description emphasizing that SE2000 was a resource enhancement policy for children with special education needs.
The special education policy of the Ministry of Education has since shifted its focus away from inclusion for disabled children, with its emphasis on supporting regular schools to teach all children. The policy now aims:

to improve learning outcomes for all children and young people with special education needs at their local school, early childhood centre, or wherever they are educated. (Ministry of Education, 2007c, italics added)

Thus, the policy currently advocates for the provision of education for disabled children across a range of settings, including segregated settings. Similarly, in 2006, the National Party's spokesperson for Education, Bill English, said that he wanted to shift thinking about inclusion by "winding the clock back" so that more children with "special" need could be educated in special schools and units (English, 2006; Radio New Zealand, 2006).

\section{Education Policy and the Competing Discourses of "Special"} and "Inclusive"

This shift in policy direction by the Ministry of Education has led to confusion at the public policy level, some documents advocating for inclusion, while others advocate for special education. Educators and the public are now faced with competing discourses about the education of disabled children.

The special education discourse is informed by neoliberal ideologies, which are now embedded within our education system. Education is viewed as a private good or a commodity, whilst the inclusive education discourse is based on notions of social justice and human rights (Ball, 1990; Ballard, 2007; Grace, 1990; Gordon \& Morton, in press; Higgins, MacArthur, \& Kelly, in press). Within the special education and neoliberal policy context, families participate in a competitive environment in which local schools, special classes, special units, and special schools compete with each other for customers. Families must evaluate the products of these various educational providers, and while the Ministry of Education's (2007d) Special Education Policy Guidelines require that such options will be thoroughly discussed, the research suggests that parents are more likely to make decisions about their disabled children's education with little support and/or with confusing guidance from the Ministry (Higgins, MacArthur \& Reitveld, 2006; Massey University, 2001). 
Ballard (2007) has suggested that, at a wider level, New Zealand imaginations are dominated by Pakeha neoliberal discourses that view humans as self-seeking and individualistic. In such a State there is a constant need to survey the worthiness of marginalised persons, such as beneficiaries, women, Maori, and disabled people, to determine the minimal amount of support that is needed to motivate them to, in a sense, "stand up on their own two feet". Within education, the turn to learning outcomes moves the education focus from the Ministry of Education's development of quality "inputs", in the form of schools and teachers, to a narrow set of contracted "outputs" from education providers and, as a result, to the assessment of the individual child's potential to reach these outcomes (Ballard, 2007; Lauder, 2005).

This focus on outputs is evident in the descriptions of hypothetical disabled children within the Ministry's ORRS (Ongoing and Reviewable Resourcing Schemes) guidelines found on its website (Ministry of Education, 2007b). For example, Jenny (4yrs $9 \mathrm{mths}$ ) is described below as a child who can be categorised as having "very high needs". The description offers a prognosis on her life course and learning outcomes during her school years:

Jenny is able to finger feed and likes to help with hand over hand spoon-feeding. She drinks from a cup with a spout. Jenny sometimes raises her arms to assist with undressing. She shows no recognition when she is wet or soiled. Jenny has learned to walk in the last year.... Jenny meets Criterion 1. This criterion is for students who have extremely delayed cognitive development. At age five they are at the earliest levels of child development.... Throughout their schooling, students will require very high levels of specialist teacher and other specialist interventions for intensive programming.... Towards the end of their schooling, the students may achieve some early developmental goals. When they leave school they will need fully supported living, working and recreational/leisure services. (Ministry of Education, 2007b)

The social child with rights who is part of the group of all children at school is de-emphasized in this portrayal of Jenny, in favour of an emphasis on the surveillance of the individual (Davis \& Watson, 2001). The portrayal selectively defines Jenny by her impairment and her bodily functions, which are intimately described, rather than reflecting respect for, or valuing of Jenny as a child at school. Jenny is thus "othered", excluded (Graham, 2006), and deemed to require a different approach to teaching and learning from her non-disabled peers.
"Specialist" services through "special" education services are required, and these services are defined as

the provision of extra help, adapted programmes, learning environments, or specialised equipment or materials to support children and young people with their learning and help them participate in education. (Ministry of Education, 2007c)

In this approach, the support that children require for learning and participation is thought of as an extra, and children can be placed in different learning environments away from their peers. Such approaches have been criticised for their capacity to view disabled children as deficit; to medicalise their lives; to differentiate them in negative ways from their peer group and to restrict their learning and rights as children (Connors \& Stalker, 2003; Graham, 2006; MacArthur, Kelly, \& Higgins, 2005; MacArthur, Kelly, Higgins, Phillips, McDonald, Morton, \& Jackman, 2005; MacArthur, Sharp, Kelly, \& Gaffney, 2007). It is at odds with the inclusive spirit of the Statement of Intent 2007-2012 and the New Zealand Curriculum (Ministry of Education, 2007a, 2007c), and it is difficult to understand how Jenny's future school can be successful in providing an education for her as promoted in these documents.

\section{From Retreat to Advance - Why Move to Inclusion?}

It is possible for the Ministry of Education to meet its stated goals of valuing, respecting, and providing her with a successful education by reframing its conceptualisation of Jenny as a child with rights in an inclusive education system and school. Inclusion, as defined by the Ministry itself, involves:

valuing all students and staff. It involves supporting all children and young people to participate in the cultures, curricula and communities of their local school. Barriers to learning and participation for all children, irrespective of their ethnicity, culture, disability or any other factor, are actively reduced, so that children feel a sense of belonging and community in their educational context. (Ministry of Education, 2007g)

At an international level, support for inclusive education can be found in a range of human rights covenants and conventions. In 2007, Vernor Munoz, the United Nations Human Rights Council's Special Rapporteur on the right to education, emphasised that the paradigm of inclusive education fitted with article 15, paragraph 1 of the International Covenant on Economic, Social and Cultural Rights; with articles 23 and 29 of the 
United Nations Convention on the Rights of the Child; with the 1994 Salamanca Statement; and with the United Nations Convention on the Rights of Persons with Disabilities 2007. New Zealand has recently signed this latter convention, which "establishes the obligation of States to ensure an inclusive education system" (Munoz, 2007, p. 2).

Further, Munoz (2007) has argued that special education needs to be dismantled in favour of one inclusive education system, because special education paradigms reinforce prejudice and discrimination towards disabled people while they "push out (from the mainstream)" students who do not measure up to performance goals" (p. 7). In contrast, theoretical and empirical advances in education show that education systems in which inclusive education discourse and paradigms dominate, limit marginalisation, are more effective for disabled children, and enrich learning for all children. Munoz concluded that radical systemic education change was needed, and that

current and future education policy must identify and remedy all structural biases leading to potential exclusion in the mainstream education system. Policies and resources aimed at developing genuinely "inclusive" practices must take precedence over the old practices. (p. 7)

\section{Advancing in a Contradictory Policy and Legislative Framework}

In New Zealand, though, when the authors did a search of the terms "inclusion" or "inclusive education" on the Ministry's website, 2670 web pages were identified for both searches, something of a "mixed bag". None of these outlined the Ministry's inclusive education policy. The results included website pages about MOE-funded research reports, job descriptions for special educators, the early childhood curriculum, and the tertiary education strategy. The policy website page to which we were referred was the Special Education Policy page. Here, the Ministry (2007c) noted that its policy is based on the fact that every child has the right to learn in accordance with the principles and values of the Education Act 1988, the National Education Guidelines, and the Special Education Policy Guidelines. The Disability Strategy is also highlighted as relevant to special education with "its aim of removing the barriers which prevent disabled people from participating fully in society" (Ministry of Education, 2007c).

However, the policy and practice associated with these listed documents are composed of confused messages about inclusive education and special education. The Education Act 1989 gives disabled children the same rights as non-disabled children to enrol in, and receive, an education in State schools (Ministry of Education, 2007c). Special schools are State schools and there is no guidance from the Ministry about whether disabled children have the same rights as non-disabled children to be included in any regular school and classroom in New Zealand. Four years later the Human Rights Act (1993) No 82 (as of December 2007), stated that it is not unlawful to refuse admission to a disabled child if a school cannot reasonably make accommodations for them:

60: Further exceptions in relation to disability

(1) Nothing in section 57 of this Act makes it unlawful to refuse admission to an educational establishment to a person whose disability is such that that person requires special services or facilities that in the circumstances cannot reasonably be madeavailable (being services or facilities that are required to enable the person to participate in the educational programme of that establishment or to enable the person to derive substantial benefits from that programme). (New Zealand Government, 1993)

The national goals of the next document that informs the Ministry's Special Education Policy, the National Education Guidelines, also seem to mix the paradigms of inclusive education and special education. The first goal notes that educational programmes need to enable all students to realise their full potential and to develop the needed values for becoming a full member of society. On the other hand, the seventh goal implies that the educational success of children with special needs is dependent upon being identified (as special), and receiving appropriate support:

Goal 7: Success in their learning for those with special needs by ensuring that they are identified and receive appropriate support. (Ministry of Education, 2007i)

In this goal, assessment and resources are emphasized, with no reference to the importance of supporting teachers to work in a classroom context where there is a valuing and respect for diversity. Thus this goal seems to fit best within the definition of special education rather than inclusive education.

The third document relevant to Special Education Policy is the Ministry's Special Education Policy Guidelines. The guidelines were developed under the SE2000 policy, and therefore include a reference 
to that policy's aim of developing a world-class inclusive education system. This aim is reflected in some of the Special Education Policy Guidelines sub-principles:

1.1 Young children and students with special education needs have access to the same range of age-appropriate education settings as other young children and students.

1.2 There is recognition of the legal right of young children and students with special education needs to enrol and attend school on the same basis as all other young children and students.

(Ministry of Education, 2007d)

However, the Special Education Policy Guidelines also emphasize the maintenance of school choice (i.e., special school or regular school) for parents (see Principles 4.2, 3.3,5). For example, clause 3.3 states that resources in special schools and units will be retained as long as children are enrolled in them (Ministry of Education, 2007d).

According to the Special Education Policy Guidelines, the Ministry will provide guidance for parents, through the provision of full information, to "make sound education choices and to participate fully in the enrolment, assessment, planning, programming, placement and monitoring of the young child or student's progress" (Ministry of Education, 2007d). In practice it would seem that such support is not forthcoming. A three year research project to evaluate and monitor the implementation of SE2000 (Massey University, 2001) showed that byand-large parents felt they had to seek out the relevant information. Parents' participation was in the main too little (they were excluded, or at least, not included in key decisions), or too much (parents said they would rather not be called every day, be asked to stand in for a teacher aide, or be required to advocate daily for their child).

\section{Advancing Inclusion in a Culture of Evidence-Based Policy and Practice}

The Ministry of Education states a commitment to developing education policy and practice that is fostered by research evidence (Ministry of Education, 2007). Nonetheless, some research undertaken in the area of special education that could contribute to empirically supported decisions seems to have been omitted from this process. For example, within the EEPiSE (Enhancing Effective Practice in Special Education) three-year longitudinal research programme, the final research reports have not been made fully available to the public. This includes the 2004 Literature review; the final report of the Pilot Study; the final 2005/2006 research reports from the four Action Research projects; and the final research reports from the Professional Learning Communities project. (Ministry of Education, 2007).

Overseas research, and some of the Ministry's own commissioned independent research, indicate that disabled students do better, both academically and socially, when they are taught in regular education settings, rather than in special schools or classes (Artiles, Crawford \& Porter, 2004; Higgins, 2006; MacArthur, Kelly, \& Higgins, 2005; MacArthur, Kelly, Higgins, Phillips, McDonald, Morton, \& Jackman, 2005; UNESCO, 2008). The ultimate litmus test comes with the research on transition to adult life which shows that education in regular schools and classrooms enhances students' learning as they transition into adulthood, promotes their wider community involvement and participation, and enhances post-school success (MacArthur, Kelly \& Higgins, 2005). These findings challenge the assumption that special education settings are preferable because they offer more intensive interventions and a higher ratio of adults to children (Fisher \& Meyer, 2002). However, this is not to say that being in the regular classroom is sufficient. The research literature strongly supports the need to focus on inclusive education policies and school change to meet the needs of diverse groups of children and young people (MacArthur, Kelly, \& Higgins, 2005).

\section{The New Zealand Disability Strategy: Advocating for Inclusion in the Shifting Sands}

The last, and perhaps most powerful Government document that advocates for inclusion, which the Ministry considers to be highly relevant to its Special Education Policy, is the Government's New Zealand Disability Strategy. The Strategy's vision is for a fully inclusive society. It states:

New Zealand will be inclusive when people with impairments can say they live in a society that highly values our lives and continually enhances our full participation. (Minister for Disability Issues, 2001, p. 1)

Objective 3 of the Strategy is to "provide the best education for disabled people" (p. 2) and the related actions for achieving Objective 3 focus on disabled children's rights to receive a quality inclusive education in their local school (Minister for Disability Issues, 2001, p. 16). These actions are consistent with the Ministry's Statement of Intent 2007-2012 and the recent statement from the present Minister for Disability Issues that: 
It is generally accepted that disabled children achieve better outcomes when they attend mainstream schools and are integrated with their non-disabled peers. (Minister for Disability Issues, 2007, p. 19)

Figures recently released by the Minister for Disability Issues suggest that disabled children's attendance in mainstream classrooms has increased between 2001 and 2006 (Minister for Disability Issues, 2008).

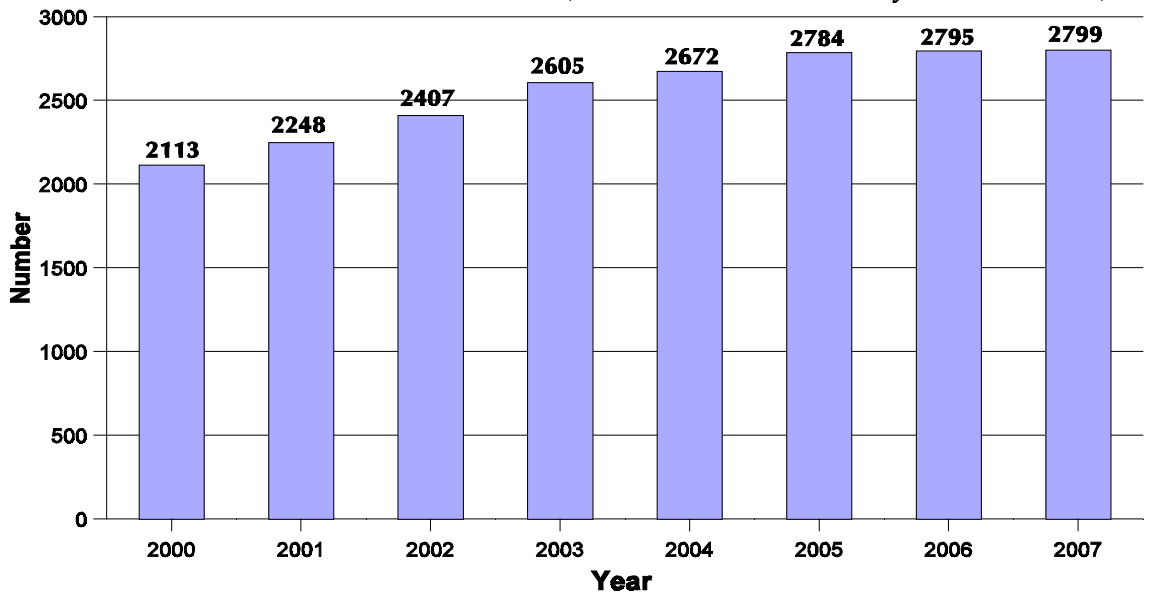

Figure 1 Special School Enrolments: 2000-2007

Yet these statistics would not appear to be borne out by the Ministry of Education's own figures, which show that between 2000 and 2007 enrolments in special schools have increased from 2113 in 2000 to 2799 in 2007 (Figure 1). This equates to an increase in special school enrolments from 0.29 percent to 0.37 percent of all enrolled students in New Zealand schools (Education Counts, 2008; Armstrong \& Armstrong, 2006). If we assume that ORRS students are most likely to attend special schools, in 2007 this would equate to 38 percent of the 7326 verified students in the high or very high needs scheme (ORRS). ${ }^{1}$ However, it is unclear if all of the students in special schools are in the ORRS.

Statistics that reveal the true picture about where disabled children are educated thus remain elusive, and we have been unable to locate Ministry of Education figures on the exact number of ORRS students in special schools, the number of special units on regular school sites, and the number of disabled children enrolled in these units.
In fact, parents seeking an inclusive education may find they have little or no choice about where their child attends school (Gordon \& Morton, in press). This point is illustrated by the real-life experience of one family, as presented at a national seminar on disabled children's rights. Duncan Armstrong and Ian Armstrong (2006) questioned whether choice is really available for families who would like to choose an inclusive education. They described their unsuccessful experience of attempting to locate a public secondary school for Duncan in the Wellington area that had a commitment to inclusion. They searched for a school that had experience in inclusive education and that did not have a special unit. Only one secondary school of seven met their requirements. Of the seven schools, one of the schools was a special school, three schools had a special unit, one school was described as hostile, and one had no experience in inclusion.

The United Nations' Special Rapporteur on the right to education recommended that States should be concerned about the exclusion of some children from community schools, and about the quality of their education. Data are thus needed in New Zealand that allow an interrogation of exclusion. The Special Rapporteur's recommendation was to ensure that States should as a minimum "adopt and revise reporting mechanisms to disaggregate data on school participation" (Munoz, 2007, p. 25).

While enrolment statistics are of considerable interest, it is also the quality of disabled children's education in the classroom and wider school that is central to an understanding of their school experience. We would argue that this is where the Ministry of Education and Office of Disability Issues need to focus their enquiries and analysis. Our own research, some of which has been undertaken for the Ministry of Education, shows a willingness and commitment by principals and teachers to include disabled children in regular classrooms. However, it also highlights a number of areas where support is needed for teachers to learn about children's impairments, their social and learning experiences at school, and pedagogical approaches based on social justice that enhance the learning of diverse groups of children (Higgins, 2006; Higgins, MacArthur, \& Kelly, in press; MacArthur, McDonald, Caswell \& Simmons-Carlsson, 2007; MacArthur, Sharp, Gaffney, \& Kelly, 2007; MacArthur, Sharp, Kelly, \& Gaffney, 2007; Morton \& Gordon, 2006). 


\section{Inclusion and Political Will}

The United Nation's Special Rapporteur indicated that States need to have the political will to move towards an inclusive education system. However, the political will of States whose education system had been decentralised, was noted as being at particularly low levels (Munoz, 2007). In New Zealand, Tomorrow's Schools has devolved the administration of education to the local level. This has caused strong change agents, such as parents of disabled children who are dispersed across the country, to become less able to meet and rally around a common national issue because their energies are focused on their local school's administration of education policy and practice. Establishing a political will to move towards an inclusive education system is also compounded by the fact that schools and parents of disabled children need to compete for limited and inadequate resources, and that in turn takes their focus away from advocating for systemic change, and returns it to the accrual of resources. In 1990, Codd warned that New Zealand's neoliberal education reforms through Tomorrow's Schools would make it more difficult to make national claims for additional resources or improvements of education quality, because there would no longer be established national channels through which to work, and because decisions about most issues would be decided at the local level. Today, there is no longer a national advocacy organisation for parents. Tomorrow's Schools originally established a national Parent Advocacy Council that was made up of parents from Boards of Trustees, but this group was disestablished by the National government in 1991, and today there is no such national advocacy group of parents.

Interestingly, there are groups dedicated to the purpose of special education that have been able to keep a national identity, and receive support from the Ministry of Education. The New Zealand Special Schools Parents Association is one such group, and the Ministry of Education hosts a statement from this group on two of its web pages, one of which provides information on "the range of special education services" available in New Zealand (Ministry of Education, 2007). The statement offers opinions on the availability of specialisations and integrated programs (the combining of therapies with teaching and learning), and on the efficacy of various placements for disabled children. No research is cited to support this statement.

Generally speaking, the specialisations increase from mainstream settings through to special schools which frequently offer integrated programmes by specialist therapists. Many special schools focus on particular disabilities such as hearing impairment, sight impairment or physical disabilities such as cerebral palsy. Many units and satellites also focus on disabilities such as ADHD, a range of intellectual disabilities and autism. Those students who have milder disabilities or needs will often respond best in the mainstream setting. Those who have significant disabilities will often respond best in a more specialised setting. However, it is not appropriate to over-generalise, as each decision must be made in the light of each student's particular needs. Each of the different types of special education service is appropriate for a range of students and represents a legitimate educational option. The diversity of special educational offerings maximises the benefits available to students with special education needs. A student's needs may well change over the course of their schooling and they may benefit from different special education settings at different times during their school years.

Some of these statements are not supported by the research. For example, Ministry of Education-funded case studies of children with physical disabilities in schools showed that a range of so-called specialisations and integrated practice were available across both segregated and mainstream education settings (MacArthur, McDonald, Simmons-Carlsson \& Caswell, 2007). What this project also showed was an advantage in favour of special schools when it came to the availability of therapies, due to therapists being located on-site. In contrast, while children in the mainstream had vastly improved opportunities for learning and socialising with their non-disabled peers and within their own communities, they faced challenges when it came to accessing therapies and integrated practice in mainstream schools because of restrictions on resources - namely, too few therapists and too little time for therapists and teachers to talk about teaching, learning and integrated practice. Several problematic systemic and resourcing issues were identified in the research, and suggestions were made to ensure that disabled children in regular schools could experience both quality learning and supportive therapies.

There is also a New Zealand Association of Special Schools Principals, which was established in 1989 to ensure parental choice, "the bank of specialist knowledge accumulated in special schools, and a voice for special schools" (New Zealand Association of Special Schools Principals, 2008b). The association also holds activities like Ministry-supported 
conferences (New Zealand Association of Special Schools Principals, 2007) and newsletters. Its mission statement is

To promote and support the professional role and the interests of New Zealand Special Schools Principals so that the status and unique learning environment of Special Schools is protected and valued. (New Zealand Special Schools Principals' Association, 2008a, italics added)

Government support for such groups that argue for a continuation of segregated education, contravenes the Disability Strategy which, commensurate with the research on inclusion, supports education for disabled children in their local schools and communities, alongside their siblings and age peers. In addition, such Government support does not sit well with New Zealand's status as a signatory to the United Nation's Convention on the Rights of the Child (UNCROC), which is written for all children, including disabled children (MacArthur, Sharp, Kelly, \& Gaffney, 2007); nor does it fit with the Convention on the Rights of Persons with Disabilities in which Article 24 links inclusive education and the right to education for disabled people:

States Parties recognize the right of persons with disabilities to education. With a view to realizing this right without discrimination and on the basis of equal opportunity, States Parties shall ensure an inclusive education at all levels and lifelong learning. (United Nations, 2007)

Davis, Watson, Corker and Shakespeare (2003) have pointed out that, in accordance with UNCROC, disabled children's rights and voices must be prioritised over those of adults when policy is developed because "professional practices get in the way of asking, and the personal prejudices and vested interests of service providers are promoted before those of children" (p. 203).

\section{Wind Back or Keep on Ticking Towards Inclusion?}

In conclusion, it might be noted that Munoz (2007) has argued that great structural and paradigm change is needed in States that wish to have inclusive education systems, and that this change needs to be grounded in clear legislative and policy statements about inclusion. Policy marks out what is significant and establishes boundaries and a framework in which schools and teachers act (Barton, 2004). New Zealand policy, though, is mixed about its commitment to inclusion, and education placement choice is emphasized instead.
Codd (2005) noted that recent Government policies have been proselytized as moving away from neoliberalism and into the "Third Way", which is supposed to offer an alternative to neoliberalism and socialism. This is achieved through a rejection of both market and State domination and by emphasizing instead, inclusiveness and social responsibility. However, Codd has argued that "Third Way" rhetoric is really a programme of political management, which is committed to neoliberalism. Our examination of New Zealand's contradictory policy rhetoric, and the focused practice in special education, reinforces Codd's argument. Education policy that concerns disabled children is still grounded in notions of education as a private good in the market, and thus New Zealand's focus is on retaining choice from a range of options - special school through to inclusive regular schools - for its education consumers, who, through surveillance and categorisation, need to demonstrate that they are worthy of receiving extra or special resources from the State. We have argued here that this is highly problematic because of the inherent contradictions with key UN Conventions on children's and disabled peoples' rights. Equally, this backward move is inconsistent with the growing body of education research evidence, both overseas and in New Zealand, that advocates for the development of inclusive education policies and practices. We argue that the State needs to get the "clock ticking forward again" and focus on the rights of disabled children, and all children, to receive a quality inclusive education in their local school, within a broader ideological framework that promotes social justice and the social inclusion of all members of society.

Note

1. Personal email, in answer to enquiry from Dr. Nancy Higgins, February 26, 2008.

\section{References}

Ainscow, M. (1999). Understanding the development of inclusive schools. London: Falmer Press.

Armstrong, D., \& Armstrong, I. (2006, November). Where Are We Now? A family experience of secondary school inclusion. Paper presented in the 2006 IHC Children's Rights Seminar Series, Wellington.

Artiles, A., Kozleski, G., Dorn, S., \& Christensen, C. (2006) Learning in inclusive education research: Remediating theory and methods with a transformative agenda, Review of Research in Education, 30, 65-108. 
Ball, S. J. (1990). Politics and policy making in education: Explorations in policy sociology. London: Routledge.

Ballard, K. (2004). Children and disability: Special or included? Waikato Journal of Education, 10, 315-326.

Ballard, K. (2007, December). Education and imagination: Strategies for social justice. The invited Herbison Lecture presented at the annual conference of the New Zealand Association for Research in Education, University of Canterbury, Christchurch.

Barton, L. (2004). The politics of special education: A necessary or irrelevant approach. In L. Ware (Ed.), Ideology and the politics of (in)exclusion (pp. 63-75). New York: Peter Lang.

Bevan-Brown, J. (2006). Beyond policy and good intentions. International Journal of Inclusive Education, 10(2-3), 221-234.

Booth, T. (2002). The index for inclusion: Developing learning and participation in schools. In K. Nes, T. O. Engen, \& M. Stromstad (Eds.), Unitary school - Inclusive school: A conference report (pp. 57-73). Hamar: Norway.

Brown, D., \& Thomson, C., (2005). Special education policy: Meeting the challenges of diversity. In J. Codd \& K. Sullivan (Eds.), Education policy directions in Aotearoa New Zealand (pp. 161-173). Southbank, Victoria: Thomson Learning Australia.

Caroll-Lind, J., Bevan-Brown, J., \& Kearney, A., (2007). Critique of the New Zealand Draft Curriculum: An inclusive/special education perspective. Retrieved on January 28, 2008, from

<www.minedu.govt.nz/web/downloadable/d111958_v1/ carroll-lind--bevan-brown--kearney-draft-curric-re.doc $>$.

Codd, J. (1990). Education policy and the crisis of the New Zealand State. In S. Middleton, J. Codd, \& A. Jones (Eds.), New Zealand Education Policy Today (pp. 191-236). Wellington: Allen \& Unwin.

Codd, J. (2005). Education policy and the challenges of globalisation: Commercialisation or citizenship. In J. Codd \& K. Sullivan (Eds.), Education policy directions in Aotearoa New Zealand. Southbank, Victoria: Thomson Learning Australia.

Connors, C., \& Stalker, K. (2003). The views and experiences of disabled children and their siblings: A positive outlook. London: Jessica Kingsley Publishers.
Davis, J. \& Watson, N. (2001). Where are the children's experiences? Analysing social and cultural exclusion in "special" and "mainstream" schools. Disability and Society, 16(5), 671-687.

Davis, J., Watson, M., Corker, M., \& Shakespeare, T. (2003). Reconstructing disability, childhood, and social policy in the UK. In C. Hallett \& A. Prout (Eds.), Hearing the voices of children: Social policy for a new century (pp. 192-209). London: Routledge.

Education Queensland. (2001). The Queensland school reform longitudinal study: A strategy for shared curriculum leadership: A teacher's summary, 2001. Retrieved on February 20, 2008, from

$<$ www.education.qld.gov.au/public_media/reports/ curriculum-framework/qsrls/index.html $>$.

Education Review Office (ERO). (2005). An evaluation of the Ongoing and Reviewable Resource Schemes. Wellington: ERO.

Education Counts. (2008). School Roll Summaries. Retrieved on February 20, 2008, from

<www.educationcounts.govt.nz/publications/series/ school_roll_summary_reports/july_school_roll_returns/ school_roll_summary_report_july_2007>;

$<$ www.educationcounts.govt.nz/publications/series/ school_roll_summary_reports/july_school_roll_returns/ school_roll_summary_report_july_2006>;

$<$ www.educationcounts.govt.nz/publications/series/ school_roll_summary_reports/july_school_roll_returns/ school_roll_summary_report_july_2005>;

$<$ www.educationcounts.govt.nz/publications/series/ school_roll_summary_reports/july_school_roll_returns/ school_roll_summary_report_july_2004>; and

$<$ www.educationcounts.govt.nz/publications/series/ school_roll_summary_reports/july_school_roll_returns/ school_roll_summary_report_july_2003>.

English, B. (2006, July). Address to the National Party Conference. Retrieved on January 28,2008 , from

$<$ billenglish.co.nz/index.php?/archives/33-Address-to-theNational-Party-Conference-21-to-23-July,-2006.html > .

Fisher, M., \& Meyer, L. (2002). Development and social competence after two years for students enrolled in inclusive and self-contained 
educational programs. Research and Practice for Persons with Severe Disabilities, 27(3), 165-174.

Gordon, L., \& Morton, M. (in press). Inclusive education and school choice: Democratic rights in a devolved system. In S. Gabel \& S. Danforth (Eds.), Disability and the politics of education: An international reader. New York: Peter Lang.

Grace, G. (1990). The New Zealand Treasury and the commodification of education. In S. Middleton, J. Codd, \& A. Jones (Eds.), New Zealand education policy today: Critical perspectives (pp. 27-52). Wellington: Allen \& Unwin.

Graham, L. J. (2006). Caught in the net: A Foucaultian interrogation of the incidental effects of limited notions of inclusion. International Journal of Inclusive Education, 10(1), 3-25.

Higgins, N. (2006). James Hargest College: No crumbs please; A case study from the South Island EEPiSE Action Research Project. A commissioned report for the Ministry of Education. Dunedin: Dunedin College of Education.

Higgins, N., MacArthur, J., \& Kelly, B. (in press). Including disabled children at school: Is it as really as simple as "A, C, D" ? International Journal of Inclusive Education.

Higgins, N., MacArthur, J. \& Reitveld, C. (2006). Higgledy-Piggledy policy: Confusion about inclusion. Childrenz Issues, 10(1), 30-36.

Kearney, A., \& Kane, R. (2006). Inclusive education policy in New Zealand: Reality or ruse? International Journal of Inclusive Education, 10(2-3), 201-219.

Lauder, H. (2005). Foreword. In J. Codd \& K. Sullivan (Eds.), Policy directions in Aotearoa New Zealand (pp. xvii-xviii). Southbank, Victoria: Thomson Learning Australia.

MacArthur, J., Kelly, B., \& Higgins, N., (2005). Supporting the learning and social experiences of students with disabilities: What does the research say? In D. Frazer, R. Moltzen, \& K. Ryba (Eds.), Learners with special needs in Aotearoa New Zealand (pp. 49-73). Southbank, Victoria: Thomson Press.

MacArthur, J., Kelly, B., Higgins, N., Philips, H., McDonald, T., Morton, M., \& Jackman, S. (2005). Building capability in education for students with moderate and high needs. A literature review commissioned by the Ministry of Education. Wellington: Ministry of Education.
MacArthur, J., McDonald, T., Caswell, P., \& Simmons-Carlsson, C. (2007). Integrated effective service provision for children and young people with physical disabilities: Case studies. Wellington: Ministry of Education.

MacArthur, J., Sharp, S., Gaffney, M., \& Kelly, B. (2007). Does it matter that my body is different? Disabled children, impairment, disability and identity. Childrenz Issues, 11(2), 25-30.

MacArthur, J., Sharp, S., Kelly, B., \& Gaffney, M. (2007). Disabled children negotiating school life: Agency, difference, and teaching practice. International Journal of Children's Rights, 15(1), 99-120.

Massey University College of Education. (2001). Special Education 2000: Monitoring and evaluation of the policy. Phase Three Final Report. (Chapter 17: Parent and Caregiver Issues). Wellington: Ministry of Education.

Millar, R., \& Morton, M. (2007). Bridging two worlds: Special education and curriculum policy. International Journal of Inclusive Education, 11(2), 163-176.

Minister for Disability Issues. (2001). The New Zealand disability strategy: Making a world of difference: Whakanui Oranga. Wellington: Ministry of Health.

Minister for Disability Issues. (2007). Work in Progress, 2007: The annual report from the Minister for Disability Issues to the House of Representatives on implementing the New Zealand Disability Strategy. Wellington: Ministry of Social Development.

Ministry of Education. (1996). Special Education 2000. Wellington: Learning Media.

Ministry of Education. (2007). Enhancing effective practice in special education. Retrieved on February 25, 2008, from

$<$ www.minedu.govt.nz/index.cfm?layout $=$ document\& documentid $=9793$ \&indexid $=9825$ \&indexparentid $=7961>$.

Ministry of Education. (2007a). New Zealand Curriculum. Wellington: Ministry of Education.

Ministry of Education. (2007b). ORRS Guidelines (2006). Retrieved on February 12, 2008, from

$<$ www.minedu.govt.nz/index.cfm?layout $=$ document \& documentid $=5323 \&$ indexid $=7962$ \&indexparentid $=10637>$. 
Ministry of Education. (2007c). Special Education Policy. Retrieved on February 4, 2008, from

$<$ www.minedu.govt.nz/index.cfm?layout $=$ document \&

documentid $=7327$ \&indexid $=7954$ \&indexparentid $=6871>$.

Ministry of Education. (2007d). Special Education Policy Guidelines. Retrieved on February 6, 2008, from

$<$ www.minedu.govt.nz/index.cfm?layout $=$ document\& documentid $=8936 \&$ indexid $=7954 \&$ indexparentid $=6871>$.

Ministry of Education. (2007e). Statement of Intent: 2007-2012. Wellington: Ministry of Education.

Ministry of Education. (2007f, September). Statement on special education in New Zealand from New Zealand Special Schools Parents Association. Retrieved on February 21, 2008, from

$<$ www.minedu.govt.nz/index.cfm?layout $=$ document $\&$

documentid $=10770$ \&indexid $=10637$ \&indexparentid $=7956>$,

and from $<$ www.minedu.govt.nz/index.cfm?layout=document\& documentid $=12292 \&$ indexid $=7954 \&$ indexparentid $=6871>$.

Ministry of Education. (2007g). Terms used in special and general education. Retrieved on February 26, 2008, from

$<$ www.minedu.govt.nz//index.cfm?layout=document\&

documentid $=7300 \&$ indexid $=7954 \&$ indexparentid $=6871>$.

Ministry of Education. (2007h). The National Administration Guidelines (NAGS). Retrieved on February 25, 2008, from www.minedu.govt.nz/index.cfm?layout =document\& documentid $=8187 \&$ data $=1>$.

Ministry of Education. (2007i). The National Education Goals (NEGS). Retrieved on February 25, 2008, from

<www.legislation.govt.nz/act/public/1993/0082/latest/ DLM304641.html?search=qs_act_human + rights + act\#DLM304641 > .

Morton, M., \& Gordon, L. (2006, April). In the public good? Preparing teachers to be inclusive educators: A New Zealand research project. Paper presented at Education Research in the Public Interest, the annual conference of the American Educational Research Association, San Francisco.

Munoz, V. (2007). The right to education of persons with disabilities: Report of the Special Rapporteur on the right to education. United Nations Human Rights Council, Fourth Session, Item 2 of the agenda. Retrieved on February 8, 2008, from
<siteresources.worldbank.org/DISABILITY/Resources/NewsEvents/463933-1147810251877/UNSREdu.pdf $>$.

Nakken, H., \& Pijl, S. (2002). Getting along with classmates in regular schools: A review of the effects of integration on the development of social relationships. International Journal of Inclusive Education, 6(1), 47-61.

New Zealand Government. (1993). Human Rights Act (1993) No 82 (as of December 2007). Retrieved on February 10, 2008, from $<$ www.legislation.govt.nz/act/public/1993/0082/latest/ DLM304641.html?search=qs_act_human + rights + act\#DLM304641>.

New Zealand Association of Special Schools Principals. (2007). Special Newsletter, Term 4, 2006. Retrieved on February 28, 2008, from $<$ www.specialschools.org.nz/index.php?module=documents\&Jas_ DocumentManager_op $=$ viewDocument\&JAS_Document_id $=5>$.

New Zealand Association of Special Schools Principals. (2008a). New Zealand Special Schools Principals Association Constitution. Retrieved on February 28, 2008, from

$<$ www.specialschools.org.nz/index.php? module $=$ pagemaster\& PAGE_user_op $=$ view_page\&PAGE_id $=4 \& M M N \_$position $=8: 8>$.

New Zealand Association of Special Schools Principals. (2008b). New Zealand Association of Special Schools Principals' website. Retrieved on February 28, 2008, from <www.specialschools.org.nz>.

Radio New Zealand. (2006, July 22). Audio report on speech by the Honorable Bill English. Wellington: Radio New Zealand.

Slee, R. (2001). Inclusion in practice: Does practice make perfect? Educational Review, 53(2), 113-123.

UNESCO (United Nations Educational, Scientific and Cultural Organization). (2008). Education: Inclusive Education.

Retrieved on February 24, 2008, from

$<$ portal.unesco.org/education/en/ev.php-URL_ID $=11891 \&$ URL_DO $=$ DO_TOPIC\&URL_SECTION $=201 . \bar{h} \mathrm{tml}>$.

United Nations. (2007). Convention on the rights of persons with disabilities. Retrieved on February 26, 2008, from $<$ www.un.org/disabilities/convention/conventionfull.shtml>.

Wills, R. (2006). Special Education 2000: A New Zealand experiment. International Journal of Inclusive Education, 10(2-3), 189-199. 


\section{The authors}

Dr Nancy Higgins is a senior researcher at the Donald Beasley Institute. Her background is in education for blind children, and she has lectured in inclusive education at the University of Otago and Dunedin College of Education. Her research interests include inclusion, social and education policy, and organisational culture. She has been a researcher in the Ministry of Education-funded Enhancing Effective Practice in Special Education research programme, and is presently the project coordinator for two HRC (Health Research Council) projects entitled, Growing Up Kāpo Māori: Whānau, Identity, Cultural Well-being and Health and Working in Intellectual Disability Services: Staff Retention and Turnover.

Dr Jude MacArthur is a freelance researcher who was formally a senior researcher at the Donald Beasley Institute. Her background is in primary teaching, and she has worked as a lecturer in education at the University of Otago where her work focused on inclusive education. Her research interests include the school experiences and identity of disabled children, and the implications for schools that teach diverse groups of children. She is an advisor on the Curriculum Exemplars and Learners with Special Education Needs Ministry of Education research project, and has recently completed a project entitled Disabled and Nondisabled Children's Construction of Identity - The Influence of School Experiences, for the Marsden fund.

Dr Missy Morton is is a principal lecturer in the School of Educational Studies and Human Development, University of Canterbury. Her interests include disability studies in education, inclusive education, teaching and learning for social justice and research methodology. Her current research includes the ways disability and research are constructed in legal settings; and teacher education, professional learning and inclusive education. She is project coordinator for the research project Curriculum Exemplars and Learners with Special Education Needs funded by the Ministry of Education. 